\title{
顎変形症手術の前後における顎関節症状の 推移に関する臨床統計的観察
}

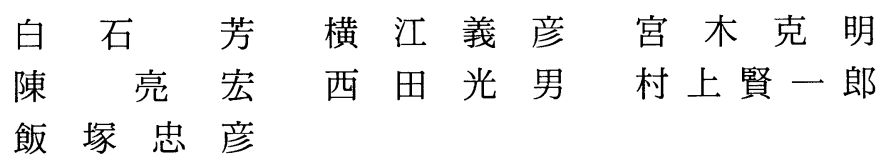

\section{Clinicostatistical Study on Changes of Temporomandibular \\ Joint Symptoms, before and after Orthognathic Surgery}

\author{
KAORI SHIRAISHI, YoshiHIKo YOKOE, Katsuaki MIYAKI, \\ LIANQ-HORNG CHEN, Mitsuo NISHIDA, KEN-ICHIRO MURAKAMI \\ and TADAHIKO IIZUKA
}

\begin{abstract}
Clinical dysfunctional symptoms (clicking and pain) of the temporomandibular joint in 278 patients before and after orthognathic surgery were reviewed retrospectively following orthognathic surgery. All patients underwent bilateral sagittal splitting osteotomy for correction of the mandibular prognathism. The sapphire screws were applied for rigid internal fixation of the fragments in 235 patients and the circumferential wire fixation was performed in 43 patients.

A significant difference in the period of intermaxillary fixation was found for patients were applied screw fixation (an average of 10.9 days) than those who were applied wire fixation (an average of 33.5 days).

It was found that the incidence of temporomandibular joint symptoms in patients who were applied screw fixation had significantly decreased than those who were applied wire fixation after surgery. In addition, the incidence of symptomatic patients with mandibular asymmetry was higher than those with symmetry, preoperatively.
\end{abstract}

Key words : temporomandibular joint symptoms (䫟関節症状), sagittal splitting osteotomy（下顎枝 矢状分割法), rigid fixation with screw（スクリュー固定）

[Received Jul. 7, 1993]

\section{緒言}

顎変形症症例には顎関節症状を伴っている場合 がしばしば見受けられる。その症状は顎変形症手 術術後に消失を見ることもあるし，逆に術前に症 状がなかった患者に出現する場合もある。また近
年顎関節症の治療において手術などにより積極的 に下顎頭位を改善しょうとする試みがなされてお $り^{11}$ ，顎関節症状を有する顎変形症患者において は顎矯正手術はひとつの治療法と言える。一方， 従来より rigid な骨片の固定による預関節に対す る影響が指摘されている。そこで今回われわれは

京都大学医学部口腔外科学教室（主任：飯塚忠彦教授）

Department of Oral and Maxillofacial Surgery, Faculty of Medicine, Kyoto University

(Chief : Prof, Tadahịiko IIZUKA) 
これら顎変形症症例を対象に術前術後の顎関節症 状の推移について検討を行い，また骨片固定法の 相違が顎関節に与える影響についても合わせて検 討したので報告する。

\section{対象および方法}

昭和 55 年 1 月から平成 3 年 12 月までの 12 年間に 当科で手術を行った顎変形症患者のらち，顎関節

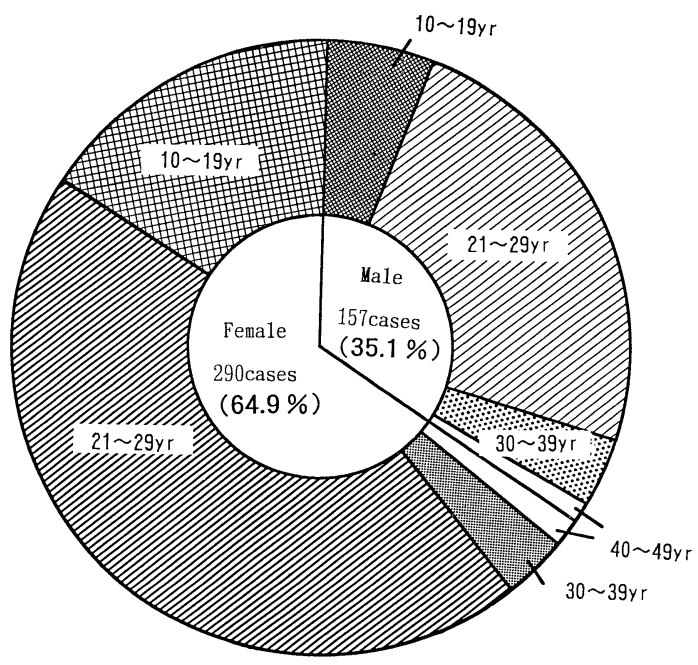

(Dept. of OMS, Faculty of Med. Kyoto Univ : 1980.1 1991.12)

Fig. 1 䫟変形症手術症例における性別および年齢 分布

Surgical treatment of 447 cases with maxillofacial deformity. (Variance of sex and age)
症状につき術前ならびに術後 1 年以上経過時点で 観察可能であったものは447例で, 男性157例, 女性 290例であった。平均年齢は男性が23.7歳, 女性が 20.0歳であった (Fig. 1)。

施行した術式の内訳は，下顎枝矢状分割法単独 施行例が 278 例で全体の $62 \%$ 占めており, 次いで 下顎前方歯槽骨切り術単独施行例が71例，上下顎 前方歯槽骨切り術施行例が 44 例であった（Fig. 2)。このうち今回は下䫟枝矢状分割法単独施行例 の術前術後の顎関節症状の推移について比較検討 をおこなった。

対象は下顎枝矢状分割法単独施行例 278 例で, 全 例下顎の後方移動症例であった。下顎枝矢状分割 法は，全例 Obwegeser 原法により行い，また特 別な装置などによる外側骨片の位置復元法は一切 行わす，従来より当科で行って来た手術法 ${ }^{2} に よ$ り外側骨片の位置決めを行った。

骨片の固定法について分類するとワイヤー固定 施行例は43例で，スクリュー固定施行例は235例 であった。使用したスクリューは当科で開発した 下顎枝矢状分割法用セラミックボーンスクリュ ー3)で，これを左右側各 2 ないし 3 本を用いて内 外側骨片の固定を行った。全症例の平均観察期間 は34.1か月である。なお，ワイヤー固定はすべて 下顎枝部での囲繞結紮法である。

内側骨片移動量は，ワイヤー固定が平均 6.66

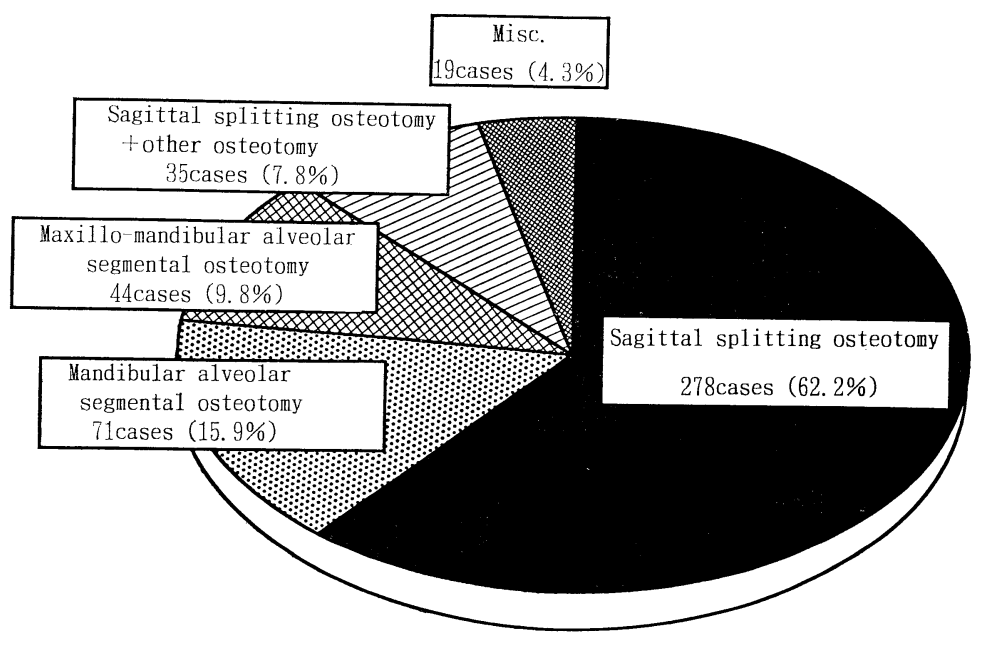

Fig. 2 手術術式内訳

Distribution of surgical techniques used for correction of maxillofacial deformity, 
$\mathrm{mm}$ で，スクリュー固定は平均 $7.03 \mathrm{~mm}$ であり， 両者の間には有意差は認められなかった。顎間固 定期間は，ワイヤー固定は平均 33.5 日，スクリュ 一固定は平均10.9日で， $\mathrm{t}$ 検定において両者の間 に0.01\%未満の危険率で有意差を認めた（Table 1)。

䫟関節症状としては, 術前術後のクリックおよ び開閉口時痛の有無についてのみ評価した。評価 はいずれも術前ならびに手術後 1 年以上経過した 時点で行い，明らかな開口障害を示した症例は認

Table 1 対象 症 例

278 patients were undergone by the bilateral sagittal splitting osteotomy.

The sapphire screws were used to fix the fragments in 235 patients and the circumferential wire fixation was perfomed in 43 patients.

\begin{tabular}{l|l|l|}
\hline Sagittal splitting osteotomy & 278 cases \\
\hline $\begin{array}{l}\text { wire fixation } \quad 43 \text { cases } \\
\text { screw fixation }\end{array} 235$ cases \\
\hline $\begin{array}{l}\text { Distance of setback } \\
\text { of mandibular } \\
\text { internal fragment } \\
\text { (average : mm) }\end{array}$ & $\begin{array}{l}\text { The period of } \\
\text { intermaxillary } \\
\text { fixation } \\
\text { (average : days) }\end{array}$ \\
\hline wire fixation & 6.66 & $33.5-$ \\
screw fixation & 7.03 & $10.9-$ \\
\hline
\end{tabular}

$(*: \mathrm{p}<0.0001)$
められなかった。

\section{結 果}

1. 固定法による比較

（ワイヤー固定とスクリュー固定）

(1)ワイヤー固定症例の顎関節症状の推移

ワイヤー固定43例中症状を訴えた症例は術前 8 例 $(18.6 \%)$ で，術後10例（23.2\%）と増加を認 めた (Fig. 3)。

術前症状のなかった 35 例のうち 8 例 $(22.9 \%)$ において術後に症状が認められた。一方, 術前ク リックを認めた 6 例のうち 4 例は術後消失し，ま た術前疼痛を訴えた 2 例はともに術後に症状の消 失を認めた (Fig. 4)。

(2)スクリュー固定症例の顎関節症状の推移

スクリュー固定 235 例中症状を訴えた症例は術 前53例 $(22.6 \%)$, 術後42例 $(17.9 \%)$ で, ワイヤ 一固定症例と異なりスクリュー固定症例において は術後に頇関節症状を訴える症例は減少していた (Fig. 5)。

術前症状を認めなかった 182 例のうち，23 例 (12.6\%) に術後に症状が出現した。一方術前に クリックを認めた40例のうち27例は症状消失し， また術前クリックと疼痛を認めた 11 例のうち 5 例 は症状が消失していた (Fig. 6)。

2. 下顎非対称症例と対称症例の比較
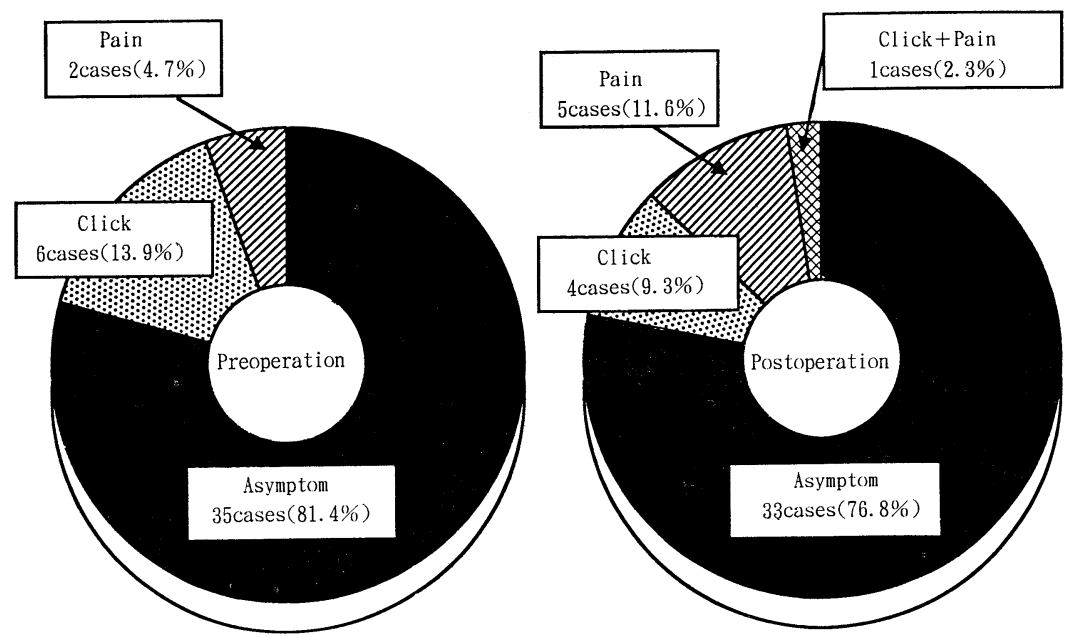

Fig. 3 ワイヤー固定症例における䪽関節症状

The temporomandibular joint symptoms ușed wịre fixation. (43 patients) 


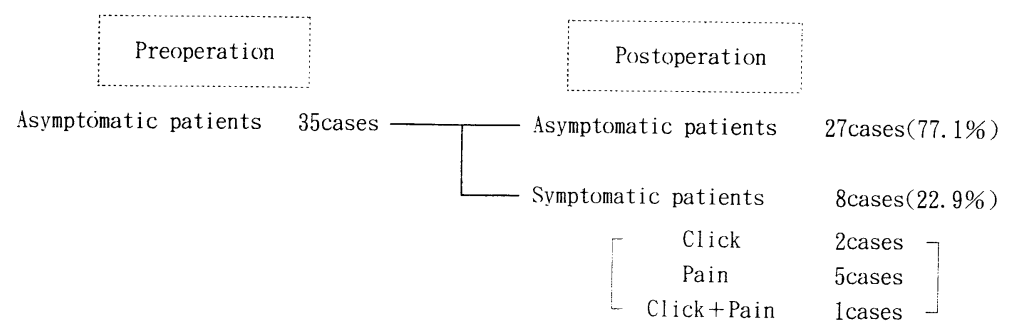

Symptomatic patients 8cases

\begin{tabular}{|c|c|c|c|}
\hline \multirow{2}{*}{ Click } & \multirow{2}{*}{6 cases } & \multirow{2}{*}{$\begin{array}{l}\text { Asymptomatic patients } \\
\text { Symptomatic patients }\end{array}$} & \multirow{2}{*}{$\begin{array}{l}4 \text { cases } \\
2 \text { cases }\end{array}$} \\
\hline & & & \\
\hline $\mathrm{P}$ & $2 \mathrm{coc}$ & Asvmptomatic patients & 2 \\
\hline
\end{tabular}

Fig. 4 手術前後の顎関節症状の推移（ワイヤー固定症例） 43 patients with wire fixation were examined for preand post-operative symptoms of temporomandibular joint.

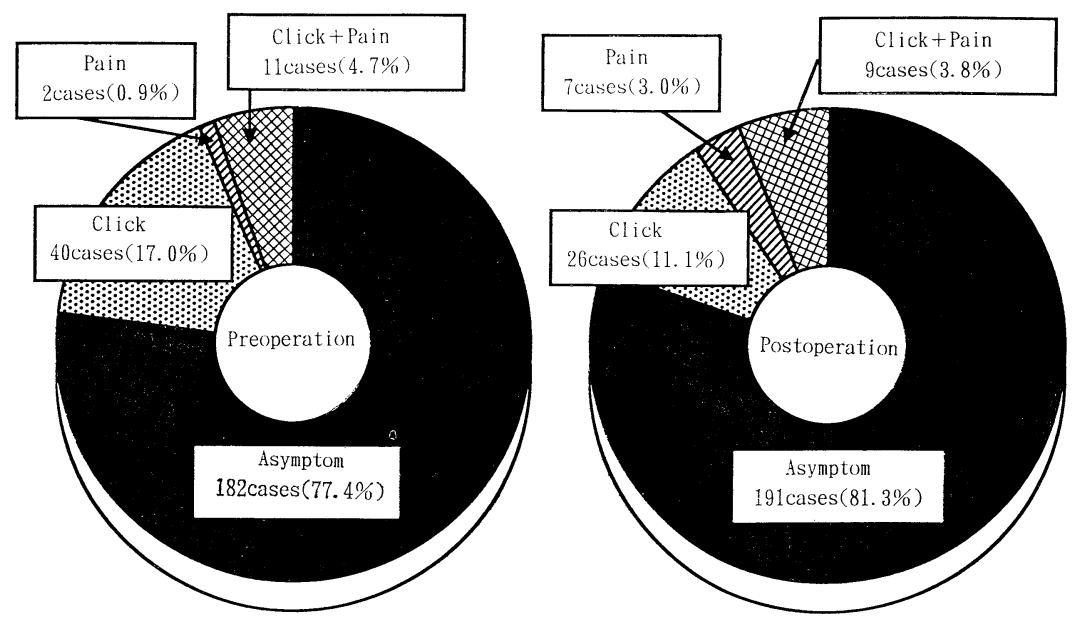

Fig. 5 スクリュー固定症例における顎関節症状

The temporomandibular joint symptoms used screw fixation. (235 patients)

下顎正中が顔面正中に対して $2 \mathrm{~mm}$ 以上左右 いずれかに偏位し，また正貌において明らかに下 顎非対称を認めたものを下顎非対称症例とし，ス クリュー固定施行例を対象に対称症例群との比較 を行った。

スクリュー固定 235 例中非対称症例は 107 例，対 称症例は128例であった。術前に顎関節症状を認め た症例は対称症例群では全体の $17.2 \%$ にどまっ たのに対し，非対称症例群では $29.0 \%$ を占めてい た。術後顎関節症状を訴える症例は両群とも減少 し，改善傾向を示した (Fig. 7，8）。
3. 内側骨片移動方向による症状変化 内側骨片の移動方向とクリック症状の関係につ いて, 手術前後で症状変化を認めた症例について 検討した。

(1)術後クリック出現例

術前無症状であったが術後にクリックが出現し た症例は13例であった。左側へ移動した際，右側 に症状が出現したものが 4 例と最も多かったが, 移動方向と発症側との間に相関は認められなかっ た (Table 2)。

(2)術後クリック消失例 


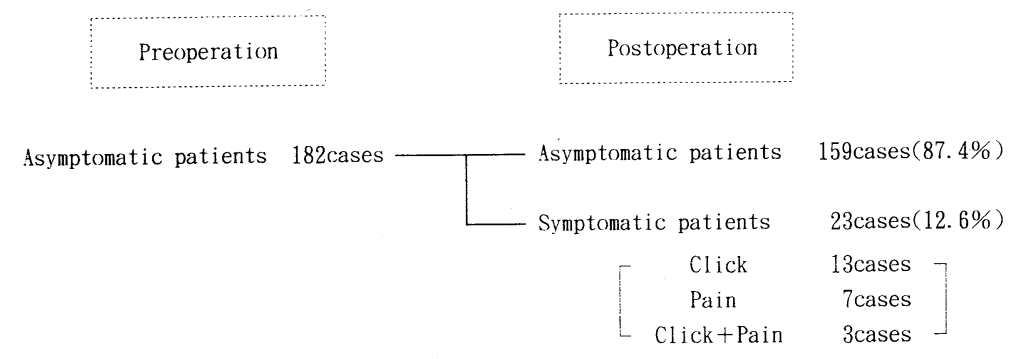

Symptomatic patients 53 cases

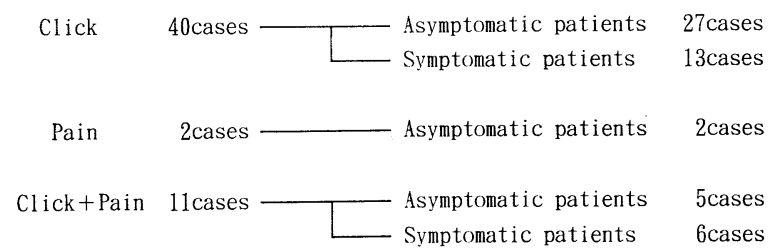

Fig. 6 手術前後の顎関節症状の推移（スクリュー固定症例）

235 cases with screw fixation were examined for pre- and post-operative symptoms of temporomandibular joint.
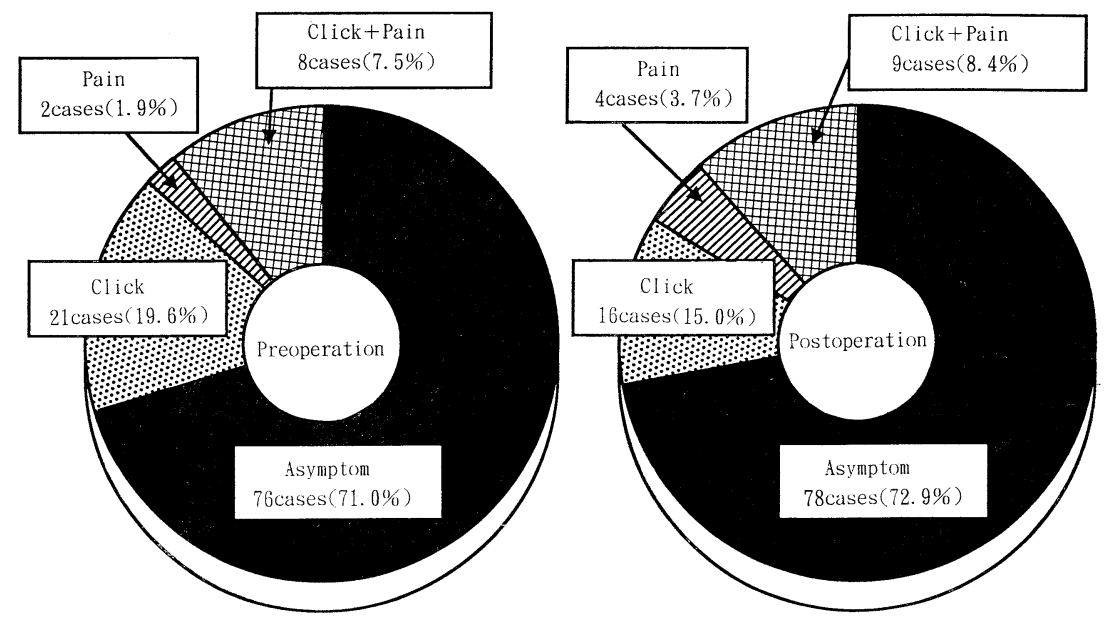

Fig. 7 下顎非対称症例における顎関節症状の推移

107 patients with asymmetry were examined for pre- and post-operative symptoms (click and pain) of temporomandibular joint.

術前にクリックを認めたが術後消失した症例は 27例であった。右側にクリックを認めた症例にお いて右側への骨片移動により消失した症例は 6 例, 同様に左側クリック症例に対する左側への移動に より症状消失した症例は 6 例, 両側にクリックを 認め後方移動することによって症状消失を認めた 症例は 7 例であった。すなわち術後のクリックの 消失を認めた症例は, 術前クリックを認めた患側
方向へ移動したものが多かった（Table 3)。

\section{考察}

従来より下顎枝矢状分割法において骨片の rigid な固定による顎関節への影響が危惧されて おり，ネジ止め固定症例における顎関節の機能障 害に関する報告む散見される。Nitzan ら ${ }^{4)}$ は, rigid な固定により術後に強直症が生じた症例を 

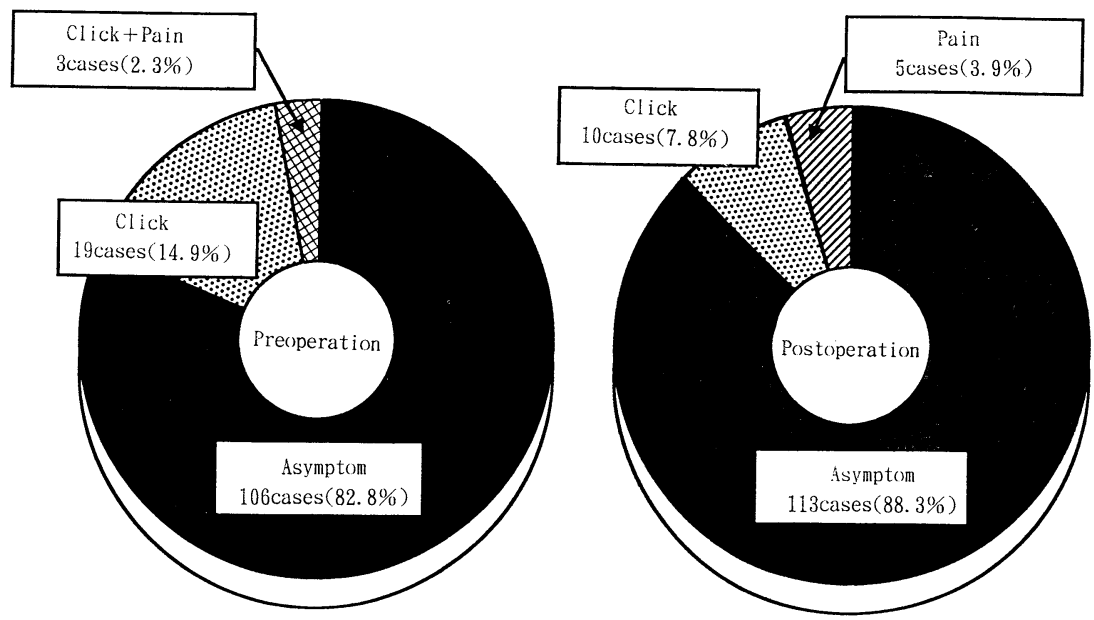

Fig. 8 下顎対称症例における顎関節症状の推移

128 patients with symmetry were examined for pre- and post-operative symptoms (click and pain) of temporomandibular joint.

Table 2 術後クリック出現例における内側骨片 移動方向との関係

Preoperative asymptomatic 13 cases developed clicking of temporomandibular joint after sagittal splitting osteotomy.

-Direction of setback of mandibular internal fragment-

\begin{tabular}{cccc}
\hline \multirow{2}{*}{ Direction of setback } & \multicolumn{3}{c}{ Affected side } \\
\cline { 2 - 4 } & right & left & bilateral \\
\hline right & 2 & 2 & 0 \\
left & 4 & 2 & 0 \\
posterior & 1 & 0 & 2 \\
\hline
\end{tabular}

Table 3 術後クリック消失例における内側骨片 移動方向との関係

Preoperative symptomatic 27 cases with improved clicking of temporomandibular joint after sagittal splitting osteotomy.

-Direction of setback of mandibular internal fragment-

\begin{tabular}{cccc}
\hline \multirow{2}{*}{ Affected side } & \multicolumn{3}{c}{ Direction of setback } \\
\cline { 2 - 4 } & right & left & posterior \\
\hline right & 6 & 0 & 2 \\
left & 2 & 6 & 2 \\
bilateral & 2 & 0 & 7 \\
\hline
\end{tabular}

報告しているが，これらの症例は平均年齢が 35.6 歳と比較的高く，また顎間固定期間が $6 \sim 8$ 週と 長期にわたる症例であった。今回検討した自験例 278 例においては，スクリュー固定施行例の顎間 固定期間は平均10.9日であり，術後に開口障害を 認めた症例はなかった。一方, Paulus ら $5^{5)}$ も クリュー固定施行例において，顎関節症状の増加 傾向は認められなかったとしているが，スクリュ 一固定症例とワイヤー固定症例とを比較したわれ われの検討結果でも，固定法の違いによる顎関節 症状の発現頻度に明らかな差異はなく，むしろス クリュー固定法において術後，顎関節症状を有す る割合は減少していた。その原因としては，両者 の顎間固定期間に有意な差が認められたことによ ることからも，顎関節症状の発現には固定法の違 いよりもむしろ固定期間の長短に起因するのでは ないかと推察された。

術前の顎変形の症型と顎関節症状の発現との関 係をみると，下顎非対称症例において，Karabouta $ら^{6)}$ は術前34例中12例（35.3\%）に預関節症状 を認めたとしているが，自験例においても同様に 107例中 31 例（29.0\%）に症状を認めた。また下顎 対称症例において，術前に顎関節症状を訴えた症 例は128例中 21 例（17.2\%）であり，下顎非対称症 例の方が術前より顎関節症状を訴える症例が多く 認められた。術後は非対称症例，対称症例ともに 
顎関節症状の改善傾向を認めた。

顎変形症手術前後において顎関節症状が変化す ることはこれまでにも報告されているが，内側骨 片の移動方向と顎関節症状との関連について検討 すると，術前にクリックを認めた患側の方向に移 動した症例に術後クリックが消失したものが多か った。これは内側骨片を患側方向へ移動させた場 合，顎間固定解除後，内側骨片に術前の位置へ復 位しようとする力が働き，それに伴い患側の外側 骨片には反対側への力が加わるため下顎頭がやや 前方位をとったためではないかと推察された。ま た患側への内側骨片の移動に伴う外側骨片の多少 の離開によって下顎頭のアンギュレーションが変 化し，その結果，関節にかかる荷重が減少したた めではないかとも推察されるが今回の検討では明 確な判断はできない。

今回は画像診断等による客観的, 計測的な検討 は行わなかったが，Eriksson ら゙は，関節造影 による検討を行い，顎変形症手術前後におりる関 節円板の位置変化について, 円板の位置が正常化 しているものもあれば転位を認めるものもあった と述べている。また顎変形症手術による円板の位 置への影響を指摘しているものの, 円板の位置と 臨床症状との関連性については言及していない。 今回術前術後の顎関節の症状の推移について臨床 統計的な検討を行ったが，今後下頂頭位のみなら ず関節円板，筋などの軟組織の変化を含めた顎変 形症手術前後の顎関節症状についての検討が必要 と考えられた。

\section{結語}

1. 下顎枝矢状分割法単独施行例 278 例について
術前術後のクリックおよび開閉口時痛の有無につ いて検討した。

2. 骨片固定法により顎間固定期間を比較する とスクリユー固定例は平均 10.9 日, ワイヤー固定 例は平均33.5日であり，両者の間に有意差を認め た。

3. ワイヤー固定施行例と比較してスクリュー 固定施行例の方が術後，顎関節症状を有する割合 は減少していた。

4. 術前顎関節症状を訴える症例は下顎対称症 例と比較して非対称症例に多く認められた。

\section{参考文献}

1) Bell, W. H. et al. : Treatment of temporomandibular joint dysfunction by intraoral vertical ramus osteotomy. Int J Adult Orthodo Orthognath Surg $5: 9-27,1990$.

2）飯塚忠彦: 預変形症の治療一下顎枝矢状分割法の基 本手術操作と要点一, 日口外誌, 38:190-193, 1992 .

3) Iizuka, T., et al.: A New Material (Single Crystal Sapphire Screw) for Internal Fixation of the Mandibular Ramus, J. Cranio-Max. -Fac. Surg. $15: 24-27,1987$.

4) Nitzan, D. W.: Temporomandibular joint fibrous ankylosis following orthognathic surgery: report of eight caces, Int J Adult Orthodo Orthognath Surg $4: 7-11,1989$.

5) Paulus, G. W., et al. : A comparative study of wire osteosynthesis versus bone screws in the treatment of mandibular prognathism, Oral Surg $54: 2-6,1982$.

6) Karabouta, I., et al.: The TMJ Dysfunction Syndrome before and after Sagittal Split Osteotomy of the Rami, J. max-fac. Surg. $13: 185-188$, 1985.

7) Eriksson, L., et al. : Changes in TMJ Disk Position Associated with Orthognathic Surgery, Oral Maxillofac Surg Clin North Am 2 : 691-698,1990. 